\title{
Konseling Individual dengan Teknik Motivational Interviewing untuk Menangani Penyesuaian Sosial pada Remaja Tindak Pidana Pencurian di Yayasan Sahabat Kapas Karanganyar
}

\author{
Swastika Rizki Nareswari \\ IAIN Surakarta, Solo, Indonesia \\ rizkinares05@gmail.com \\ Alfin Miftahul Khairi \\ IAIN Surakarta, Solo, Indonesia \\ alfin3207@gmail.com \\ Ahmad Nafi' \\ IAIN Salatiga, Salatiga, Indonesia \\ nafiahmad028@gmail.com
}

\begin{abstract}
Abstrak
Penelitian ini bertujuan untuk mengetahui proses layanan konseling individual dengan Teknik Motivational Interviewing untuk menangani penyesuaian sosial pada remaja tindak pidana pencurian di Yayasan Sahabat Kapas Karanganyar. Metode penelitian menggunakan metode kualitatif deskriptif. Teknik pegumpulan data menggunakan wawancara, observasi, dan dokumentasi. Hasil penelitian menunjukkan bahwa konseling individual dengan Teknik Motivational Interviewing akan maksimal dengan cara mengimpelemntasikan empat prinsip untuk menangani penyesuaian sosial
\end{abstract}

Kata kunci: Konseling Individual, Motivational Interviewing, Penyesuaian Sosial

\section{Abstract}

Individual Counseling with Motivational Interviewing Techniques to Deal with Social Adjustments in Adolescent Criminal Theft in 
Yayasan Sahabat Kapas Karanganyar. This study aims to determine the process of individual counseling services with Motivational Interviewing Techniques to deal with social adjustment in adolescent criminal acts of theft at the Sahabat Kapas Karanganyar Foundation. The research method uses descriptive qualitative methods. Data collection techniques using interviews, observation, and documentation. The results showed that individual counseling with Motivational Interviewing Techniques would be maximized by implementing four principles to deal with social adjustment

Keywords: Individual Counseling, Motivational Interviewing, Social Adjustment

\section{A. Pendahuluan}

Masa remaja merupakan masa peralihan dari anak-anak menuju dewasa yang ditandai dengan ketergantungan hideup dengan orang lain, pada masa ini merupakan masa dalam mencari identitas diri. Menurut G. Stanley Hall masa remaja berlangsung pada umur 12 sampai dengan 22 tahun, di mana masa tersebut merupakan masa goncangan yang ditandai dengan konflik dan perubahan suasana hati (Santrock, 2003). Faktor lingkungan mempengaruhi pada pembentukan jiwa seseorang. Indonesia merupakan negara yang perkembangan penduduknya sangat pesat. Sehingga menciptakan kondisi sosial dan ekonomi, sehingga menimbulkan masalah dalam bidang keamanan dan kenyamanan masyarakat, seperti kenakalan remaja. Kenakalan remaja sudah menjadi masalah di lingkungan masyarakat, diantaranya penyalahgunaan narkoba, pembunuhan, dan pencurian.

Tindak pidana pencurian adalah gejala sosial yang senantiasa dihadapi oleh masyarakat. Dalam hukum kriminal, pencurian adalah pengambilan properti milik orang lain secara tidak sah tanpa izin pemilik. Tindak pidana pencurian di atur dalam KUHP Pasal 362 yang berbunyi "barang siapa mengambil barang sesuatu, yang seluruhnya atau sebagian kepunyaan orang lain, dengan maksud untuk dimiliki secara melawan hukum, diancam karena pencurian, dengan pidana penjara paling lama 5 tahun atau pidana denda paling banyak sembilan ratus rupiah". Selain itu pencurian juga diatur dalam KUHP Pasal 363, 364, 365, dan 367. 
Menurut (Ahmadi, 2002) konseling individual adalah seperangkat usaha pemberian bantuan kepada individu yang menghadapi permasalahan pribadinya, mengadakan penyesuaian, memilih jenis-jenis kegiatan yang ingin diikutinya dan kegiatan rekreatif yang bernilai guna, serta berdaya upaya sendiri dalam memecahkan masalah-masalah pribadinya. Tujuan konseling dalam penelitian ini adalah membantu remaja mencapai tujuan konseli yang berguna bagi masyarakatnya dan menangani permasalahan penyesuaian sosial. Konseling individual sangat dibuthkan di lapas, karena anak-anak di sana sangat membutuhkan seseorang yang mampu menjadi pendengar yang baik untuk menceritakan permasalahannya dan memberikan solusi. Di dalam konseling terdapat beberapa teknik, salah satunya adalah teknik motivational interviewing.

Teknik motivational interviewing merupakan Teknik yang berfokus pada individu untuk membantu mengeksplorasi dan mengatasi ambivalensi dalam mengubah perilaku. Tujuannya untuk mengidentifikasi dan meningkatkan motivasi klien tentang perubahan yang konsisten pada diri klien. Fungsi dari Teknik ini adalah meningkatkan otonomi klien dan rasa tanggung jawab klien untuk mengambil keputusan klien.

Setiap orang diharapkan mampu memiliki penyesuaian sosial yang baik, karena ia akan terjun ke dunia bebas, tetapi disisi lain harus menghadapi perubahan yang berbeda dari kehidupan sebelumnya. Jadi penyesuaian diri secara sosial merupakan proses yang melibatkan respon mental tingkah laku setiap individu dalam menghadapi kondisi sosial agar tercipta keadaan yang harmonis satu sama lain. Penyebab seseorang mengalami kesulitan melakukan penyesuaian sosial dikarenakan minder, gelisah, dan sulit bersosialisasi. Remaja di LPKA memiliki kesulitan melakukan penyesuaian sosial terutama permasalahan mereka dalam menghadapi pandangan negatif yang kemungkinan akan terjadi, mengembalikan kepercayaan masyarakat dan juga mengembalikan kepercayaan keluarga kepada konseli. 
Berdasarkan hasil observasi dan wawancara hampir semua remaja di LPKA Klas 1 Kutoarjo mampu menangani permasalahan penyesuaian sosial karena beberapa hal yang membuat mereka kesulitan, diantaranya anggapan negative masyarakat dan penerimaan keluarganya. Di LPKA terdapat 60 anak, hampir semua anak mengalami penyesalan akibat perbuatannya dan ketakutan setelah keluar dari lapas. Setiap remaja memiliki motivasi yang memberikan perubahan positif, sehingga konselor menggunakan Teknik MI utuk mengembangkan motivasi yang ada pada diri klien.

Salah satu Lembaga yang menangani permasalahan penyesuaian sosial pada remaja di lapas tersebut adalah Yayasan Sahabat Kapas, Yayasan tersebut merupakan organisasi non pemerintah yang memberikan pendampingan psikologis, pengembangan diri, pelatihan keterampilan dan dukungan reintegrasi bagi Anak Berhadapan dengan Hukum (ABH). Penelitian ini bertujuan untuk mengetahui proses layanan pelaksanaan konseling individual dengan teknik Motivational Interviewing untuk menangani penyesuaian sosial pada remaja tindak pidana pencurian di Yayasan Sahabat Kapas Karanganyar.

\section{B. Pembahasan}

\section{Konseling Individual}

Konseling Individual adalah layanan bimbingan konseling yang memungkinkan konseli mendapatkan layanan langsung tatap muka (secara perorangan) dengan konselor dalam rangka membahas tentang pengentasan masalah pribadi yang diderita konseli (Hellen, 2005). Menurut Prayitno (Prayitno \& Amti, 2014) fungsi layanan konseling individual adalah 1) fungsi pemahaman, 2) fungsi pencegahan, 3) fungsi pengentasan, 4) fungsi pemeliharaan dan pengembangan, 5) fungsi advokasi. Tujuan konseling individual menurut Gibson, 
Mitchell, dan Basile yaitu perkembangan, pencegahan, perbaikan, penyelidikan, penguatan, kognitif, fisiologis dan psikologis.

Di dalam konseling individual terdapat 3 tahapan diantaranya; tahap awal yaitu membangun kedekatan dengan konseli agar konseli lebih terbuka dan konselor lebih mudah dalam mengidentifikasi masalah, tahap kedua yaitu tahap inti dengan memberikan konseling dan pemberian solusi permasalahan kepada konseli, tahap ketiga atau tahap akhir yaitu tahap dalam menyelesaikan masalah dan adanya evaluasi.

\section{Teknik Motivational Interviewing}

Miller dan Rollnick mendefinisikan Motivational Interviewing proses untuk membantu klien dalam mengembangkan motivasi intrinsik untuk merubah dan mencapai tujuan konseling (Erford, 2015). Teknik MI terdapat 3 komponen yaitu:

1. Collaboration yaitu kerjasama antara konselor dengan konseli untuk mengeksplorasi motivasi dengan cara suportif.

2. Evocation yaitu melibatkan konselor professional memperpanjang motivasi klien.

3. Autonomy yaitu meletakkan tanggung jawab untuk berubah pada klien, dan menghormati kehendak bebas.

Tahan dan Sminkey berpendapat bahwa konselor yang menggunakan teknik Motivational Interviewing harus memiliki kecerdasan emosional substansial dan kesadaran akan berbagai emosi reaksi kekuatan, dan bidang tantangan baik di dalam dirinya maupun orang lain (Erford, 2015). Menurut Miller dan Rollnick teknik MI memiliki 4 prinsip umum diantaranya:

a. Mengekspresikan empati, untuk membangun kepercayaan konseli dan meyakinkan bahwa konselor menerima apa adanya konseli, sehingga memberikan rasa nyaman kepada konseli. 
b. Mengembangkan diskrepansi, membantu konselor secara terampil dalam menjelaskan perasaan dan pemikiran konseli.

c. Menerima resistensi, keterampilan konselor dalam mengembalikan kepercayaan klien

d.Mendukung efikasi diri, konselor dapat mendorong keyakinan dan mendukung perubahan untuk memperbaiki diri konseli.

\section{Penyesuaian Sosial}

Schneiders (Schneiders, 2014) penyesuaian sosial adalah kemampuan untuk bereaksi secara efektif dan sehat terhadap situasi, realitas dan relasi sosial sehingga tuntutan hidup bermasyarakat dipenuhi dengan cara yang dapat diterima dan memuaskan. Berdasarkan pengertian di atas dapat disimpulkan bahwa penyesuaian sosial merupakan suatu proses berkomunikasi untuk menyesuaikan diri terhadap orang lain atau kelompok sesuai dengan kesadaran dirinya dan tuntutan dalam lingkungan sekitarnya.

\section{Remaja}

Remaja berasal dari kata latin adolescence yang berarti tumbuh atau tumbuh menjadi dewasa. Menurut Sri Rumini \& Siti Sundari (Prasanti, 2018) masa remaja adalah masa peralihan dari masa anak-anak menuju dewasa yang mengalami semua aspek/fungsi untuk memasuki dewasa. Dari definisi di atas dapat disimpulkan bahwa masa remaja adalah masa peralihan dari masa anakanak menuju dewasa dengan rentan usia antara 12-22 tahun, di mana masa tersebut terjadi proses pematangan baik itu pematangan fisik maupun psikologis. Tahapan remaja ada 3 yaitu: remaja awal (early adolescence), remaja madya (middle adolescence), remaja akhir (late adolescence).

\section{Tindak pidana pencurian}

Tindak pidana berasal dari kata "strafbaar feit" berasal dari bahasa Belanda yang artinya tindak pidana, delik, perbuatan pidana, peristiwa pidana maupun perbuatan yang dapat dipidana. Jonkers (Ilyas, 2012) merumuskan bahwa 
Strafbaar feit artinya suatu perbuatan yang melawan hukum yang berhubungan dengan kesengajaan atau kesalahan yang dilakukan oleh orang yang dapat dipertanggungjawabkan. Dari segi bahasa etimologi pencurian berasal dari kata "curi" yang artinya adalah sembunyi-sembunyi atau diam-diam atau tidak dengan jalan yang benar/sah atau melakukan pencurian secara sembunyi-sembunyi atau tidak diketahui orang lain atas perbuatan yang dilakukannya.

Pengertian tindak pidana pencurian diatur dalam Pasal 362 KUHP yang dirumuskan sebagai berikut:

"Barang siapa mengambil sesuatu barang, yang sama sekali atau sebagian termasuk kepunyaan orang lain, dengan maksud akan memiliki barang itu dengan melawan hak, dihukum, karena pencurian deengan hukuman penjara selamalamanya lima tahun atau denda sebanyak-banyaknya Rp.900,-."

Jenis-Jenis Tindak Pidana Pencurian

1. Pencurian Biasa

Perumusan pengertian pencurian terdapat dalam Pasal 362 KUHP yang berbunyi:

"Barang siapa yang mengambil sesuatu barang yang seluruhnya atau sebagian milik orang lain dengan maksud untuk memiliki barang tersebut dengan melawan hukum, dipidana karena pencurian dengan hukuman penjara selamalamanya 5 tahun atau denda setinggi-tingginya Rp. 900,00."

2. Pencurian dengan Pemberatan

Pencurian yang diatur dalam Pasal 363 KUHP dan Pasal 365 KUHP dinamakan dengan kualifikasi. Sebab dari istilah tersebut dapat dilihat bahwa karena sifatnya maka pencurian tersebut diperberat ancaman pidananya.

3. Pencurian Ringan

Pencurian ini adalah pencurian yang nilainya sangat rendah, yaitu barang yang diambil tidak bernilai lebih dari Rp. 25,00 menjadi Rp. 250,00, dengan ancaman 
pidana hanya minimum 3 bulan penjara atau denda setinggi-tingginya Rp. 60,00 dinaikkan 15 kali.

4. Pencurian dengan Kekerasan

Dalam Pasal 365 KUHP, menyebutkan bahwa:

a. Diancam dengan pidana penjara selama-lamanya 9 tahun, pencurian yang didahului, disertai, atau diikuti dengan kekerasan, terhadap orang, dengan maksud mempersiapkan atau mempermudah pencurian, atau dalam hal tertangkap tangan, untuk memungkinkan melarikan diri sendiri atau peserta lainnya, atau untuk tetap menguasai barang yang dicuri.

b. Diancam dengan penjara paling lama 12 tahun.

\section{METODE}

Penelitian ini bersifat kualitatif menurut Bodgan dan Taylor yaitu, metodologi penelitian kualitatif merupakan prosedur penelitian yang menghasilkan data deskriptif berupa kata-kata tertulis atau lisan dari orang-orang dan perilaku yang diamati (Moleong, 2014). Sedangkan menurut Krik dan Miller definisi penelitian kualitatif adalah tradisi tertentu dalam ilmu pengetahuan sosial yang secara fundamental tergantung pengamatan pada manusia dalam kawasannya sendiri dan berhubungan dengan orang-orang tersebut dalam pembahasan dan istilahnya (Moleong, 2014). Peneliti menggunakan metode penelitian deskriptif kualitatif karena peneliti ingin mengeksplor fenomena untuk meningkatkan penyesuaian sosial pada remaja yang dilaksanakan di Yayasan Sahabat Kapas.

Data yang diperlukan dalam penelitian ini berdasarkan makna yang dikomunikasikan secara langsung atau isyarat dalam ekspresi wajah. Maka dari itu peneliti menggunakan teknik pengumpulan data yaitu wawancara semi terstruktur, observasi terus terang/tersamar dan dokumentasi. Keabsahan data yang digunakan dalam penelitian ini adalah triangulasi data untuk mempertanggung jawabkan kebenarannya secara ilmiah. Triangulasi merupakan 
teknik pemeriksaan keabsahan data yang memanfaatkan sesuatu yang lain untuk keperluan pengecekkan atau sebagai pembanding data (Sugiyono, 2008).

\section{DISKUSI}

Dari hasil observasi penelitian terhadap remaja di LPKA klas 1 Kutoarjo yang mendapatkan konseling individual dari konselor Sahabat Kapas mengalami permasalahan penyesuaian sosial sesuai dengan tahapan-tahapan konseling individual pada umumnya. Pelaksanaan konseling individual tersebut berjalan dengan baik dan mampu menangani permasalahan penyesuaian sosial yang dialami oleh remaja tindak pidana pencurian. Konseling di LPKA Klas 1 Kutoarjo dilakukan setiap 2 minggu sekali oleh konselor Sahabat Kapas, dan konseling dilakukan hanya pada satu kali waktu dari tahap pertama hingga tahap terakhir.

Saat konseling berlangsung, konselor berperan seperti teman sebaya yang mampu memberikan solusi permasalahannya, sehingga mereka merasa aman dan nyaman ketika bercerita. Dalam pelaksanaan konseling individual tersebut terdapat 3 tahapan, diantaranya tahap awal ini konselor melakukan pendekatan dengan klien agar konselor mendapatkan kepercayaan penuh dari klien mampu mengidentifikasi masalah yang dialami oleh klien. Tahap pertengahan, dalam tahap ini konselor memberikan solusi permasalahan yang dialami oleh klien dengan cara membantu klien untuk membangkitkan motivasi yang ada pada diri konseli. Tahap akhir merupakan tahap untuk menentukan penyelesaian masalah dan dilanjutkan evaluasi.

Dalam konseling tersebut terdapat proses teknik motivational interviewing diantaranya

1. Mengekspresikan empati, konselor memberikan empatinya dengan cara diam dan mendengarkan dengan seksama saat AMF bercerita tetag permasalahannya, selain itu konselor mengucapkan kepada konseli bahwa ia memahami perasaan yang sedang dialami AMF. Hal tersebut membuat AMF lebih percaya kepada konseli. 
2. Mengembangkan diskrepansi, konselor membantu AMF secara terampil ketika menjelaskan perasaan dan pikirannya. Konselor menggunakan pertanyaan terbuka yang membantu AMF mendeskripsikan tentang kehidupan sehari-harinya. Kemudian AMF menceritakan kegiatannya di rumah sebelum masuk ke lapas bahwa ia bekerja dan membantu ibunya di rumah. Selain itu konselor juga menawarkan saat sesi MI ini dengan cara menyimpulkan penyebab AMF bisa masuk ke lapas.

3. Menerima resistensi, dalam sesi ini konselor sangat menjaga kepercayaan AMF, konselor selalu memastikan bahwa ia benar-benar mendengarkan cerita yang disampaikannya.

4. Mendukung efikasi diri, konselor mendukung penuh perubahan positif seperti saat AMF mengatakan akan berubah dan tidak mengulangi perbuatannya lagi, AMF akan membuktikan kepada masyarakat bahwa mantan narapidana tidak selalu buruk, agar tidak dipandang sebelah mata dan AMF akan membuktikan bahwa dirinya akan sukses.

Saat pelaksanaan konseling individual dengan teknik MI yang dilakukan oleh konselor Sahabat Kapas kepada remaja tindak pidana pencurian di LPKA Klas 1 Kutoarjo memberikan perubahan dalam hal penyesuaian sosial, karena konseli menyadari pentingnya penyesuaian sosial bagi kehidupannya. Selain itu konselor juga membantu konseli membangkitkan motivasi yang ada pada diri konseli. AMF merupakan remaja perempuan yang melakukan pelanggaran pasal 363 yaitu pencurian yang dilakukan di daerah asalnya. Berikut gambaran perilaku AMF sebelum mengikuti kegiatan konseling, AMF memiliki permasalahan suka menyendiri dan melamun akibat memikirkan kehidupannya pasca lapas.

Faktor yang menyebabkan AMF sulit melakukan penyesuaian sosial ketakutannya menghadapi statement negatif dari masyarakat akibat perilaku yang dilakukannya dan semua kemungkinan yang akan terjadi di masyarakat. Selain itu juga takut terkena tuduhan kembali ketika terjadi pencurian lagi. Pemikiran 
tersebut membuat AMF menjadi orang yang kesulitan melakukan penyesuaian social sehingga ia menjadi orang yang suka menyendiri.

Peneliti menganggap penyesuaian sosial merupakan hal yang sangat penting karena setiap orang akan membuthkan bantuan orang lain untuk bersosialisasi dan setiap orang tidak bisa hidup sendiri tanpa bantuan orang lain. Setelah dilakukan konseling individual AMF mulai mengalami perubahan dalam hal penyesuaian sosial, sikapnya yang sering melamun dan menyendiri sudah mulai berkurang karena sudah mau bergabung dengan teman. Selain itu AMF juga mengalami perubahan yang positif dari perilakunya, AMF mulai tertib sholat 5 waktu dan mengikuti kegiatan yang sudah disediakan oleh lapas dan sudah mau berinteraksi dengan pegawai di lapas. Statement negatif masyarakat akan dijadikan motivasi oleh AMF untuk berubah. Tindakan AMF setelah keluar dari lapas berupa perubahan positif seperti AMF bekerja dengan giat untuk membuktikan kepada masyarakat bahwa ia tidak selamanya buruk, menumbuhkan kepercayaan masyarakat, dan juga belajar untuk menjadi pribadi yang lebih baik.

Dari proses konseling di atas menunjukkan bahwa masalah penyesuaian sosial pada remaja setelah mendapatkan konseling mengalami perubahan yang positif. Hal ini menunjukkan bahwa pemberian konseling individual pada remaja di lapas sangat penting dan efektif untuk mengatasi penyesuaian sosialnya. Hal tersebut sesuai dengan fungsi konseling individual yaitu pengetasan masalah.

\section{Simpulan}

Untuk menangani penyesuaian sosial pada remaja tindak pidana pencurian melalui konseling individual denga teknik motivtional interviewing dapat disimpulkan bahwa: faktor penyebab mereka sulit melakukan penyesuaian sosial yaitu ketakutan mereka menghadapi kehidupan setelah keluar dari lapas. 
Statement negatif dari masyarakat membuat mereka kebingungan menghadapinya, selain itu mereka juga takut terkena tuduhan-tuduhan ketika terjadi pencurian lagi, sehingga keadaan tersebut membuat mereka menjadi pendiam dan sulit bersosialisasi.

Diberikannya konseling individual dengan teknik MI untuk menangani penyesuaian sosial tersebut sangat penting karena mereka membutuhkan seseorang yang mampu menjadi pendengar yang baik untuk mendengarkan permasalahan mereka dan memberikan solusi kepada mereka terutama untuk menghadapi kehidupan pasca lapas. Konselor Sahabat Kapas menggunakan teknik MI yang diimplementasikan melalui memberikan empati dengan cara menjadi pendengar yang baik dan ikut merasakan apa yang dirasakan oleh konseli, menerima apa adanya konseli, memberikan evaluasi, dan mendukung keyakinan konseli.

Konseling di LPKA Klas I Kutoarjo yang dilakukan oleh Yayasan Sahabat Kapas dilakukan hanya dua kali saja. Karena setiap anak yang menjalani hukuman hampir semuanya mengurus cuti bersyarat agar dapat menjalani setengah dari hukuman tersebut, selain itu keterbatasan jumlah konselor yang menangani konseling, dan keterbatasan waktu yang dilakukan dua minggu sekali serta tempat yang jauh membuat konseling hanya dilakukan dua kali. 


\section{DAFTAR PUSTAKA}

Agustin, L. (2007). Hubungan antara konsep diri dan penyesuaian sosial mahasiswa papua yang kuliah di yogyakarta. Skripsi Universitas Sanata Dharma

Ahmadi, A. (2002). Psikologi Sosial. Jakarta: Rineka Cipta.

Anggriawan, M. A. (2017). Studi Komparatif Tindak Pidana Pencurian Dalam Hukum Islam dan Hukum Pidana Indonesia. Jurnal Ilmiah, 43), 3( $\square \square \square \square$. https://doi.org/10.1017/CB09781107415324.004

Bagus, G. D., Kumara, M., Laksmi, A. A. S., \& Gayatri, D. (2019). Jurnal Analogi Hukum Penahanan Anak yang Melakukan Tindak Pidana Pencurian dengan Kekerasan (Studi Kasus Nomor: 6/Pid . Sus - Anak/2017/PN Dps ). 1(1), 62-66.

Erford, B. T. (2015). 40 Teknik yang Harus Diketahui Setiap Konselor. Yogyakarta: Pustaka Pelajar.

Gerungan, W. A (2004). Psikologi Sosial. Bandung: PT. Refika Aditama.

Gueldner, B., \& Merrell, K. (2011). Evaluation of a social-emotional learning program in conjunction with the exploratory application of performance feedback incorporating Motivational Interviewing techniques. Journal of Educational and Psychological Consultation, 21(1), 1-27. https://doi.org/10.1080/10474412.2010.522876

Hellen. (2005). Bimbingan dan Konseling. Jakarta: Quantum Teaching.

Https://Sahabat Kapas.org

Husni, M. (2017). Layanan Konseling Individual Remaja; Pendekatan Behaviorisme. 2(2).

Ilyas, A. (2012). Asas-Asas Hukum Pidana. Yogyakarta: Pukap Indonesia.

Maslihah, S. (2011). Studi Tentang Hubungan Dukungan Sosial, Penyesuaian Sosial Di Lingkungan Sekolah Dan Prestasi Akademik Siswa Smpit Assyfa Boarding School Subang Jawa Barat. Studi Tentang Hubungan Dukungan Sosial, Penyesuaian Sosial Di Lingkungan Sekolah Dan Prestasi Akademik Siswa Smpit Assyfa Boarding School Subang Jawa Barat, 10(2), 103-114. https://doi.org/10.14710/jpu.10.2.103-114 
Moleong, L. J. (2014). Metode Penelitian Kualitatif, Edisi Revisi. Bandung: PT. Remaja Rosdakarya.

Nurcahyani, L. D. (2017). Layanan konseling individu dalam mengatasi penyesuaian sosial pada remaja di lembaga pembinaan khusus anak klas 1 kutoarjo.

Nurihsan, A. J. (2006). Bimbingan Konseling Dalam Berbagai Kehidupan. Bandung: Rafika Aditama.

P. A. F Lamintang. (2012). Dasar-Dasar Hukum Indonesia. Bandung: Citra Aditya Bakti.

Prasanti, D. (2018). Penggunaan Media Komunikasi Bagi Remaja Perempuan Dalam Pencarian Informasi Kesehatan. LONTAR: Jurnal IImu Komunikasi, 6(1), 13-21. https://doi.org/10.30656/lontar.v6i1.645

Prayitno, \& Amti, E. (2014). Dasar-Dasar Bimbingan Konseling.Jakarta: Rineka Cipta.

Purbaya, A. A. (2018). Tahun 2018, Tiap 55 Menit Ada 1 Kejahatan di Jawa Tengah. https://news.detik.com/berita-jawa-tengah/d-4366115/tahun-2018-tiap-55menit-ada-1-kejahatan-di-jawa-tengah

R. Soesilo. (1995). Kitab Undang-Undang Hukum Pidana KUHP. Bogor: Politea.

Santrock, J. (2003). Psikologi Perkembangan Remaja. Jakarta: Erlangga

Schneiders, A. A. (2014). Personal Adjustment and Mental Health. New York: Holtt Renehart and Winston Inc.

Septiawan, R. R. (2019). Pengaruh regulasi emosi dan penyesuaian sosial terhadap kenakalan remaja pada siswa smp negeri 1 pageruyung kendal tahun ajaran $2018 / 2019$.

Sibarani, F., Gaol, S. A. E. L., Fachrurrazi, A., Studi, P., Hukum, I., Hukum, F., \& Indonesia, U. P. (2019). Jurnal Mercatoria. 12(11), 29-42.

Yuliantini, S. (2017). Hubungan Kecerdasan Emosi Dan Penyesuaian Sosial Dengan Kenakalan Remaja Pada Siswa SMP PGRI 7 Samarinda Seberang. Psikoborneo, 5(2), 386-399.

Sofantiyana, N. I. (2018). Teknik Motivational Interviewing untuk membekali 
penyandang disabilitas netra memperoleh subjective well-bein $g$ di rps $d n$ bhakti candrasa surakarta.

Sugiyono. (2008). Metode Penelitian Kuantitatif Kualitatif dan R\&D. Bandung: Alfabeta.

Sugiyono. (2012). Metode Penelitian Kombinasi (mixed method). Bandung: Alfabeta.

Sulistyoningsih, W. (2019). Bimbingan Individu Dengan Teknik Motivational Interviewing untuk Meningkatkan Kecerdasan Sosial Pada Anak Di Yayasan Pembinaan Anak Cacat Surakarta. 2, 5-10.

Wahidin, O. U. 2017. PENDIDIKAN KARAKTER BAGI REMAJA Oleh: Unang Wahidin*.

Wahyu, A., Rozah, U., \& Sri, A. M. E. (2016). dalam Kitab Undang-undang Hukum. 5, $1-18$. 